\title{
Research on Applying Gray GM(1,1) Model in Construction Project Cost Forecasting
}

\author{
Wang Jing ${ }^{1, a}$, Chen Zhenghui ${ }^{2, b}$ \\ ${ }^{1}$ Faculty of Architecture \& Urban Planning, Chongqing University,Chongqing, P.R.China \\ ${ }^{2}$ College of Construction Management \& Real Estate,Chongqing University,Chongqing, P.R.China \\ a474445703@qq.com, bczh19704@sina.com
}

\begin{abstract}
Keywords: Gray GM (1, 1) Model; Accuracy Test; Construction Project Cost Forecasting Abstract. On basis of doing a systemic review and summarization to various construction project cost forecasting methods and their respective characteristics, this paper analyzes the applicability of $\mathrm{GM}(1,1)$ forecasting model used in project cost forecasting, and introduces the method briefly and comprehensively. By example study this paper displays how to use the method in actual project cost forecasting, and gray system prediction model with advantages of a small sample and high-accuracy is fully exhibited.
\end{abstract}

\section{Introduction}

Nowadays various competition in construction field are becoming more and more intense. Especially with the enforcement of many new laws and regulations such as tendering and bidding system, reporting system of project construction, construction licence system and pricing specification of bill of quantities, lots of aspects for construction enterprises to obtain tasks, organize constructing, operate and manage capital and so on have induced a series of changes, which bring many new issues to the construction enterprises' project cost management. To in pursuit of survival and development in the fierce competition, constuction enterprise giving a reasonable bidding price during the process of tendering and bidding is very important. Proposed tender offer is considered mainly from cost, profit and risk undertaken procedure. Thereinto to forecast project cost accurately is a key condition and of first importance to assure and enhance the rationality of bidding price, which sometimes also becomes a problem for the project construction manager. This paper imitates to discuss a project cost forecasting method not only according with the actual characteristics of the project cost, but also with a higher forecasting accuracy of project cost based on comparative analysis of the traditional features of the project cost forecasting.

\section{Analysis of Applying Grey GM (1,1) prediction model for forecasting project cost}

Review and Comment of Various Common Project Cost Prediction Methods. The methods of project cost forecasting include two main types: qualitative and quantitative method. Qualitative forecasting is the method that experts who have rich experience and strong analysis ability make estimations on qualitative and some extent to material consumptions, market situation and cost by using their subjective experiences[1]. There have been several qualitative forecasting methods: subjective probability method, investigation judgement method, analogizing method and so on. The major advantages of qualitative forecasting are from practical experience and simple. But meanwhile some significant limitations still exist such as low accuracy, vulnerable to the impact of psychological and emotional changes then producing subjective one-sidedness.

Quantitative forecasting method is a general designation of kinds of forecasting method to establish mathematical model to predict and infer the future based on historical data and quantitative relationship between cost and influencing factors[2]. The common used methods mainly include the cost prediction model of Time Series(such as moving average method and exponential smoothing method), the cost forecasting model on causality(such as univariate linear regression forecast and 
bivariate linear regression forecast), and the prediction model of structural relationship(such as input -output analysis model and econometric model).

The cost prediction model of Time Series sets up cost development trend model based on successive statistical data, which takes time as independent variable. The result of cost in future will be obtained from assuming that the cost with some bounded conditions should continue extend along with existed trend approximately. Setting up model in this way is simple, but the localization is prediction results rather rough.

The cost forecasting model on causality may acquire comparatively perfect result on conditions of suitable model and accurate data. But the process of building model is quite complex and it need have anew estimation for model parameters even data have a little change, so applying this model to reflect the changes of economic activities is too lagging and lack of continuity.

The prediction model of structural relationship forecasts cost value in accordance with changes of structure proportion between interdependence factors. But to apply this model need grasp accurate and detailed information about each influencing factors, which is diffcult to obtain roundly.

In construction practice the project cost will be affected by a lot of uncertain factors(example of labor costs and material costs influenced by policy factor). The feature of unconspicuous regularity will lead to the forecast result from those setted up mathematical model is difficult to pass the statistical test. On the other hand, to set up above quantitative forecasting models almost need a long time accumulated historical data, so it's not easy to obtain effective result under mastering limited cost informations.

Review as above, the common used forecast models are restricted either on the accumulation of historical data or on the accuracy of the forecast. When meeting actual project influenced by uncertain factors and with limited datum, the commonly used methods are poor predictors.

The Reasons of Inducting the System Science Theory in Predicting Project Cost. On project cost forecasting, the commonly used time series data is only committed to the data fitting, do not pay attention to the discovery of the law. Basically, those statistical forecasting methods all pursue a large sample size[3] This article aims to explore a project cost forecasting method not only accord with the actual characteristics of project cost but also having good accuracy, theoretical guidance is essential.

The system science theory appeared in the second half of 20th century, which takes small-sample and uncertain system as the research objective to achieve accurate described and effective control for systemic operation action and evolution law through building, exploring and distilling valuable information from fractional known information. The theroy of system science reveals more profound and essential inherent-relationship between objective things. System science theory include various uncertainties in system theory such as Fuzzy Math found by Professor Zadeh in 60's of the 20th century and Rough Set Theory found by Professor Parac in 1980's.

Study objects of system science often meet situations when forecasting project cost, so this paper considers that under the guidance of system scientific theory the use of specific prediction method is suitable to project cost forecasting.

Principle of Gray Forecasting Model. The gray system is a new system theory proposed by Mr. Deng Julong[4], and which is an incomplete and uncertain information system. The gray system regards all random variables as gray variables that change its value in a certain range, and also regards a random process as a variational gray process. Interference from random environments make characteristic quantity of the system excessively dispersed,so series of grey variable are created by using gray system through handling original data, in which randomicity of data are weakened and regularity are strengthened. On base of above process the gray dynamic GM model is taken as a prediction model, and then methodological mechanism of rolling optimization and feedback correction should be taken to the model. 


\section{Example Study}

Hunan HT Construction Engineering Corporation Ltd. is a first-class general contracting enterprise engaged in Building Construction. April 2009 in bidding process of office buildings (frame structure with six-storey, total floor area of $18926 \mathrm{~m}^{2}$ ) construction of Yongzhou Hunan Province Local Taxation Bureau, the decision-maker took into account the specific situation of intense market competition, presented the bidding strategy "preservation and guaranteed profit slightly ", two different methods for calculating bidding price were adopted:the one was grey prediction method,the another one was calculated by quota. After synthesizing the two kinds result, the enterprise determined its bidding scheme and then won the bid finally. By limited space this is only the process of using gray prediction for a description.

When calculating tender price by Grey prediction, accounts unit price of final accounts from five projects with similar conditions were taken out from enterprise's database. Excluding the impact of accidental factors properly, taking unit price per unit area of five projects as sequence of gray prediction, obtained project cost are listed in the Table 1.

Table 1 The situation of similar projects in nearly years

\begin{tabular}{|c|c|c|c|c|c|}
\hline $\begin{array}{l}\text { Serial } \\
\text { number }\end{array}$ & Title of project & $\begin{array}{l}\text { Time of } \\
\text { project } \\
\text { completion }\end{array}$ & $\begin{array}{l}\text { Building } \\
\text { area }\left[\mathrm{m}^{2}\right]\end{array}$ & $\begin{array}{l}\text { Construction } \\
\text { cost[ten } \\
\text { thousand yuan] }\end{array}$ & $\begin{array}{l}\text { Construction } \\
\text { cost per square } \\
\text { meter[yuan/ } \\
\left.\mathrm{m}^{2}\right]\end{array}$ \\
\hline 1 & $\begin{array}{l}\text { Office building of Health Bureau of } \\
\text { Yongzhou (frame structure with eight- } \\
\text { storey) }\end{array}$ & 082006 & 16820 & 1736.615 & 1032.47 \\
\hline 2 & $\begin{array}{l}\text { Office building of Immigration } \\
\text { Authority of Yongzhou（frame } \\
\text { structure with five- storey） }\end{array}$ & 032007 & 22300 & 2528.374 & 1133.8 \\
\hline 3 & $\begin{array}{l}\text { Information building of Hunan } \\
\text { University of Science and Engineering } \\
\text { ( frame structure with eight- storey) }\end{array}$ & 062007 & 15326 & 1787.931 & 1166.6 \\
\hline 4 & $\begin{array}{l}\text { Office building of State Tax Bureau of } \\
\text { Yongzhou (frame structure with } \\
\text { seven- storey) }\end{array}$ & 102008 & 13125 & 1556.231 & 1185.7 \\
\hline 5 & $\begin{array}{l}\text { Office building of Yongzhou } \\
\text { Vocational Technical College } \\
\text { (frame structure with five- storey) }\end{array}$ & 122008 & 17952 & 2179.014 & 1213.8 \\
\hline
\end{tabular}

Let original data $X^{(0)}=\left\{X^{(0)}(1), X^{(0)}(2), \cdots, X^{(0)}(5)\right\}=\{1032.47,1133.8,1166.6$, $1185.7,1213.8\}$

By means of accumulated generating doing calculation to $X^{(0)}$, then $X^{(1)}=\{1032.47,2166.27$, $3332.87,4518.57,5732.37\}$.

Doing quasi moothness test to $\mathrm{X}^{(0)}, \mathrm{P}(\mathrm{k})=\mathrm{X}^{(0)}(\mathrm{k}) / \mathrm{X}^{(1)}(\mathrm{k}-1)$ then $\mathrm{P}(2)$ $=1133.8 / 1032.47=1.098, \mathrm{P}(3)=1166.6 / 2166.27=0.538, \mathrm{P}(4)=1185.7 / 3332.7=0.355<0.5, \mathrm{P}$

( 5 ) $=1124.5 / 4518.57=0.293<0.5$. When $\mathrm{k}>3$, the condition for quasi smoothness is satisfied.

Testing whether $\mathrm{X}^{(1}$ accord with quasi exponential law, from calculating $\sigma^{(1)}(\mathrm{k})=\mathrm{X}^{(1)} \quad(\mathrm{k})$ $/ \mathrm{X}^{(1)}(\mathrm{k}-1)$, the following figure were obtained: $\sigma^{(1)}(2)=2166.27 / 1032.47=2.099, \sigma^{(1)} \quad$ (3) $=3332.87 / 2166.27=1.538, \sigma^{(1)}(4)=4518.57 / 3332.87=1.356, \sigma^{(1)} \quad(5)=5732.37 / 4518.57=1.268$. $\mathrm{Vk}, \sigma^{(1)}(\mathrm{k}) \in[\mathrm{a}, \mathrm{b}], \mathrm{d}=\mathrm{b}-\mathrm{a}$, when $\mathrm{d}<0.5$, when $\mathrm{k}>3, \sigma \in[1,1.5]$. Quasi exponential law is satisfied,so it can establish model aiming at $\mathrm{X}^{(1 .}$

By use of the mean generation with consecutive neighbors to $X^{(1)}$, let $Z^{(1)} \quad(k)=0.5 X^{(1)} \quad(k)$ $+0.5 X^{(1)}(\mathrm{k}-1)$. Then: $Z^{(1)}=(Z(2), Z(3), \ldots, Z(5))=(1599.37,2749.37,3925.72$, 5125.49 ) 


$$
B=\left[\begin{array}{ll}
-Z^{(1)}(2) & 1 \\
-Z^{(1)}(3) & 1 \\
-Z^{(1)}(4) & 1 \\
-Z^{(1)}(5) & 1
\end{array}\right]=\left[\begin{array}{ll}
-1599.37 & 1 \\
-2749.37 & 1 \\
-3925.72 & 1 \\
-5125.49 & 1
\end{array}\right] \quad Y=\left[\begin{array}{l}
X^{(0)}(2) \\
X^{(0)}(3) \\
X^{(0)}(4) \\
X^{(0)}(5)
\end{array}\right]=\left[\begin{array}{l}
1133.8 \\
1166.6 \\
1185.7 \\
1213.8
\end{array}\right]
$$

Doing least square estimation to parameters serial $\hat{\mathrm{a}}=[\mathrm{a}, \mathrm{b}]$, it can obtained that

$$
\hat{a}=[a, b]^{\mathrm{T}}=\left(\mathrm{B}^{\mathrm{T}} \mathrm{B}\right)^{-1} \mathrm{~B}^{\mathrm{T}} \mathrm{Y}=\left[\begin{array}{l}
-0.02226 \\
1102.25
\end{array}\right]
$$

Determinating model: $\mathrm{dX}^{(1)} / \mathrm{dt}-0.02226 \mathrm{X}^{(1)}=1102.25$ and time response formula, $\hat{\mathrm{X}}{ }^{(1)}(\mathrm{k}+1)=(\mathrm{X}$ (0) (1) $-\mathrm{b} / \mathrm{a}) \mathrm{e}^{-\mathrm{ak}}+\mathrm{b} / \mathrm{a}=50549.84 \mathrm{e}^{-\mathrm{ak}}-49517.09$

Solving value of simulation of $\hat{X}=\left(\hat{X}^{(1)}\right.$ (1), $\hat{X}^{(1)}$ (2) $\left., \ldots, \hat{X}^{(1)}(5)\right)=(1032.47$, $2170.6,3334.07,4523.73,5740.17,6983.98)$

Solving simulated values of $\mathrm{X}^{(0}$ by reducing, accoring to $\hat{X}^{(0)}(\mathrm{k})=\hat{\mathrm{X}}^{(1)}(\mathrm{k})-\hat{\mathrm{X}}^{(1)}(\mathrm{k}+1)$, it can obtained that: $\hat{X}^{(0)}=\left(\hat{X}^{(0)}(1), \hat{X}^{(0)}(2), \hat{X}^{(0)}(3), \hat{X}^{(0)}(4), \hat{X}^{(0)}(5)\right)$ $=(1032.47,1137.86,1163.47,1189.66,1216.44,1243.8)$

Testing error, examination of the effect are listed in the Table 2.

Table 2 Examination of the effect

\begin{tabular}{ccccc}
\hline $\begin{array}{c}\text { Serial } \\
\text { number }\end{array}$ & $\begin{array}{c}\text { Original } \\
\text { data }\end{array}$ & $\begin{array}{c}\text { Simulated } \\
\text { data }\end{array}$ & $\begin{array}{c}\text { Residual } \\
\text { error }\end{array}$ & Relative error[\%] \\
\hline 2 & 1133.8 & 1133.86 & -4.06 & 0.358 \\
3 & 1166.6 & 1163.47 & 3.13 & 0.268 \\
4 & 1185.7 & 1189.66 & -3.96 & 0.334 \\
5 & 1324.7 & 1216.44 & -2.64 & 0.217 \\
\hline
\end{tabular}

The mean value of original data known from the Table 1: $\bar{X}=1174.98$, $S_{1}=\sqrt{\frac{1}{4} \sum_{k=1}^{4}(X(k)-\bar{X})^{2}}=41.572$

According to $\varepsilon^{(0)}(\mathrm{k})=\frac{1}{4} \sum \varepsilon(\mathrm{k})$, The mean value of residual error is calculated: ${ }^{-(0)}=1.9625$

$$
S_{2}=\sqrt{\frac{1}{4} \sum(\varepsilon(\mathrm{k})-\bar{\varepsilon})^{2}}=9.6898
$$

The ratio of residual error is $c=S_{2} / S_{1}=0.233$

The minimum error possibility $\mathrm{P}=\left\{\left|\varepsilon^{(0)}(\mathrm{k}) \cdot \bar{\varepsilon}^{(0)}\right|\right\}<0.6745 \mathrm{~S}=1$

Compared with the Table 3, its grade of precision is the first grade. Result of the estimation price of construction cost per square meter is showed in Table 4.

So calculated proposed bidding total prices with Gray GM $(1,1)$ prediction model is $18926 \times 1243.8=23540159$ Yuan, It is similar to the bidding prices 23012737 Yuan calculated by 
adopting quota. It is obvious that Gray GM $(1,1)$ model is feasible to be used in cost predicting on the basis of small-samples.

Table 3 Grade of precision test

\begin{tabular}{ccccc}
\hline $\begin{array}{c}\text { Grade of } \\
\text { precision }\end{array}$ & $\begin{array}{l}\text { Relative } \\
\text { error a }\end{array}$ & $\begin{array}{l}\text { Correlat } \\
\text { ion } \\
\text { degree } \\
\varepsilon_{0}\end{array}$ & $\begin{array}{l}\text { Ratio of } \\
\text { mean square } \\
\text { deviation } \mathrm{C}_{0}\end{array}$ & $\begin{array}{l}\text { Minimum } \\
\text { error } \\
\text { possibility }\end{array}$ \\
\hline $\begin{array}{c}\text { First grade } \\
\text { (good) }\end{array}$ & 0.01 & 0.9 & 0.35 & 0.95 \\
$\begin{array}{c}\text { Second grade } \\
\text { (qualified) }\end{array}$ & 0.05 & 0.8 & 0.5 & 0.8 \\
$\begin{array}{c}\text { Third grade } \\
\text { (grudging) }\end{array}$ & 0.1 & 0.7 & 0.65 & 0.7 \\
$\begin{array}{c}\text { Fourth grade } \\
\text { (unqualified })\end{array}$ & 0.2 & 0.6 & 0.8 & 0.6 \\
\hline
\end{tabular}

Table 4 Result of the estimation

\begin{tabular}{ccc}
\hline $\begin{array}{c}\text { Time of the } \\
\text { project }\end{array}$ & $\begin{array}{c}\text { Actual } \\
\left.\text { cost[Yuan/m } \mathrm{m}^{2}\right]\end{array}$ & $\begin{array}{c}\text { Astimation cost } \\
{\left[\text { Yuan } / \mathrm{m}^{2}\right]}\end{array}$ \\
\hline 082006 & 1032.42 & 1032.47 \\
032007 & 1133.8 & 1133.86 \\
062007 & 1166.6 & 1163.47 \\
102008 & 1185.7 & 1189.66 \\
122008 & 1213.8 & 1216.44 \\
042009 & - & 1243.8 \\
\hline
\end{tabular}

\section{Conclusion}

Project cost forecasting methods have their advantages and limitations. Many forecasting methods is restricted to apply under the project cost suffered from a great deal of uncertain factors or limited quantity of information.

This paper introduce Grey system theory GM $(1,1)$ modeling method to forecast tender project cost, which not only can establish forecast model under number of cost data limited, without considering distribution law and trend of change, but also has high reliability to precision of forecasting with computed easy. Confirmed by example result of applying Gray GM（1，1） model to predict project investment and cost is credible and satisfactory.

\section{References}

[1] J.P. Wu and X.Q. Liu: Rationality analysis of project cost forcasting method, Jianghuai Water Science and Technology, vol 3(2003)

[2] [3] S A Kuruk lis and G.Ladas :Oscillations and global attractivity in a discrete delay logistic model, Quart ApplMath, Vol.50 (1992).

[4] J.L. Deng: Gray Theory Course, Huazhong University of Science and Technology Press, Wuhan, (1990)

[5] L.J. Song: Research on controlling of constructing long span prestressed concrete Continuous girder, Southwest Jiaotong University Press, Chengdu (2007)

[6] S.F.Liu and J.L.Deng: Scope of GM ( 1 , 1 ) Model, Theory \& Practice of Systems Engineering, Vol.5(2000), P.121-124

[7] S.Z. Ding: Construction Project Management, China Building Industry Press, Beijing (2004)

[8] Y.X. Wu and Z.H. Chen: Application of gray system theory in bidding estimation for construction projects, International Conference on Management and Service Science, MASS 2009 (IEEE Press, 2009) 